Transport in the United Kingdom 


\section{Transport in the United Kingdom}

D. Maltby

Reader in Civil Engineering,

University of Salford

H. P. White

Professor of Geography,

University of Salford 
() D. Maltby and H. P. White 1982

All rights reserved. No part of this publication may be reproduced or transmitted, in any form or by any means, without permission.

First published 1982 by

THE MACMILLAN PRESS LTD

London and Basingstoke

Companies and representatives

throughout the world

Typeset in 10/11pt Press Roman by

STYLESET LIMITED

Salisbury. Wiltshire

ISBN 978-0-333-27827-7 ISBN 978-1-349-16835-4 (eBook)

DOI 10.1007/978-1-349-16835-4

The paperback edition of the book is sold subject to the condition that it shall not, by way of trade or otherwise, be lent, resold, hired out, or otherwise circulated without the publisher's prior consent in any form of binding or cover other than that in which it is published and without a similar condition including this condition being imposed on the subsequent purchaser. 


\section{Contents}

List of Figures vii

List of Tables viii

Preface ix

Statistical Sources $\quad$ xiii

1 The Transport Sector 1

1.1 Transport and Employment 1

1.2 Transport and Output $\quad 12$

1.3 Transport and Expenditure 19

1.4 Balance of Payments and External Trade 25

1.5 Central Government Management of the Economy 28

References $\quad 37$

2 The Transport System of the United Kingdom 39

2.1 The Road Network 39

2.2 Private Transport 44

2.3 Public Road Passenger Transport 46

2.4 Road Haulage $\quad 52$

2.5 The Rail System $\quad 54$

2.6 Air Transport 64

2.7 Water Transport 68

2.8 Pipelines $\quad 73$

2.9 The Organisation of Transport in Northern Ireland 75

References $\quad 76$

3 Transport Trends 79

3.1 Overall Trends in Passenger Transport 79

3.2 Trends in Domestic Passenger Transport 82

3.3 Trends in International Passenger Transport $\quad 94$

3.4 Trends in Domestic Freight Transport 97

3.5 Trends in International Freight Transport $\quad 100$

$\begin{array}{ll}3.6 \text { Transport Trends and Technological Change } & 105\end{array}$

$\begin{array}{ll}\text { References } & 108\end{array}$ 
4 Wider Relationships between Transport and Socio-economic Activity

4.1 The Reciprocal Relationship between Transport and Socioeconomic Activity

4.2 Transport and Economic Development 113

$\begin{array}{ll}\text { 4.3 Transport and Social Development } & 119\end{array}$

$\begin{array}{ll}\text { 4.4 Transport and Regional Development } & 124\end{array}$

$\begin{array}{ll}4.5 \text { Transport and Land-use Activity } & 125\end{array}$

4.6 Transport and Communications 131

$\begin{array}{ll}\text { References } & 131\end{array}$

5 Local Transport Problems and Policies 134

$\begin{array}{ll}5.1 \text { Introduction } & 134\end{array}$

$\begin{array}{ll}5.2 \text { Large Cities } & 135 \\ 5.3 \text { Medium and Smaller Towns } & 134\end{array}$

$\begin{array}{lr}5.3 \text { Medium and Smaller Towns } & 152\end{array}$

$\begin{array}{ll}5.4 \text { Rural Areas } & 155\end{array}$

$\begin{array}{ll}5.5 \text { General Conclusions } & 160\end{array}$

$\begin{array}{ll}\text { References } & 161\end{array}$

6 National Transport Problems and Policies 163

6.1 Economic Growth and Regional Development 163

$\begin{array}{ll}6.2 \text { Energy } & 166\end{array}$

$\begin{array}{ll}\text { 6.3 Transport Manufacturing } & 168\end{array}$

$\begin{array}{ll}6.4 \text { Road Transport } & 169\end{array}$

$\begin{array}{ll}6.5 \text { Rail Transport } & 178\end{array}$

$\begin{array}{lr}\text { 6.6 Air Transport } & 185\end{array}$

$\begin{array}{ll}\text { 6.7 Water Transport } & 193\end{array}$

$\begin{array}{ll}\text { References } & 197\end{array}$

$\begin{array}{ll}\text { Index } & 200\end{array}$ 


\section{List of Figures}

1.1 Employment in shipbuilding and marine engineering

1.2 Employment in vehicle manufacture

1.3 Employment in transport and communication

1.4 Transport-related employment

1.5 Index numbers of output at constant factor cost: transport manufacturing

1.6 Index numbers of output at constant factor cost: transport and communication

1.7 Index numbers of output at constant factor cost: manufacturing

2.1 The motorway network - Great Britain

2.2 The simplification of the British Railway system

2.3 Airports in the United Kingdom

2.4 Pipelines - Great Britain

3.1 Trends in passenger transport

5.1 Space per commuter/average speeds - various modes 


\section{List of Tables}

1.1(a) Sub-sectors (transport, non-transport and imports) accounting for at least 10 per cent of the production costs of transport sub-sectors in the United Kingdom in 1972

1.1(b) Transport sub-sectors accounting for at least 10 per cent of the production costs of non-transport sub-sectors

1.2 Gross domestic product by industry in $\mathbf{1 9 7 5}$

1.3 Gross domestic product by manufacturing industries in 1975

1.4 Total final output of the transport sector in 1972

1.5 Gross domestic product by industry in 1968 and 1975

1.6 Gross domestic product by industry in 1948, 1958, 1968 and 1978

1.7 Movements in the output per employee ratio in the United Kingdom.

1.8 Total final expenditure of the United Kingdom at market prices

1.9 Gross domestic fixed capital formation by sector and type of asset in the United Kingdom in 1978

1.10 Public expenditure plans for roads and transport in the United Kingdom for the 1980-81 financial year

2.1 Car ownership levels - representative wards in Greater Manchester, 1971

2.2 Planning and operation of public passenger transport England and Wales

2.3 Rank order of 30 British ports, 1976

5.1 Modal split of journey to work, 1971 - major conurbations

5.2(a) Conurbation centres

5.2(b) Modal split of journey to work, 1971 - conurbation centres

5.3 Passenger traffic entering Central London during the morning peak period

5.4 Modal split of journey to work, 1971 - selected towns 


\section{Preface}

We have written this book because we consider there is a need for a basic text for new or relatively new studnets of United Kingdom transport. We have in mind candidates for Chartered Membership of the Institute of Transport, undergraduates at universities, polytechnics, and other colleges of higher education reading transport as a minor or major subject, and postgraduates at universities and polytechnics attending courses of advanced study in transport, or conducting transport research. In addition, it provides background information for students of economics, geography, political science, and planning who wish to look at the relationship between transport and their own particular areas of interest. We also have in mind less formal students of this fundamental human activity with such widespread economic and social implications, such as politicians, journalists, members of environmental groups, or people who simply wish to increase their knowledge of transport in the United Kingdom for its own sake.

We have deliberately written the book, then, for a very disparate readership in terms of background, discipline and experience. At undergraduate level in universities and polytechnics, transport studies tend to have a minor role within such disciplines as civil engineering, economics and geography, although there is the exception of their forming a whole degree course at three universities and a subject in a joint degree at another, while they form courses of study leading to examinations for Corporate Membership of the Chartered Institute of Transport at other institutions of higher education. It is likely that most students on postgraduate courses in transport at universities and polytechnics have read transport as a minor subject in their undergraduate course, but some will be meeting transport studies formally for the first time. So the new or relatively new students of transport studies for whom we have written this book are to found throughout the spectrum of higher education.

The book is aimed primarily at the student of United Kingdom transport. We have written the book for a United Kingdom context for two principal reasons: firstly, our joint expertise based on study of transport over some 45 years relates primarily to the United Kingdom; secondly, it is very difficult writing international texts on transport because of national differences in policy, institutions, and methodology. None the less the main lessons of this book can be applied through parallel to countries with comparable political and economic frameworks to those of the United Kingdom. 
The main reason why we think there is a need for a book such as this lies in the inter-disciplinary and complex nature of most transport problems on one hand, and the very wide spectrum of disciplines from which students of transport come, on the other. Although our basic disciplines are civil engineering and geography, respectively, we have only developed inter-disciplinary personal approaches to transport studies after many years of experience. Our main aim with this book is to speed up this process for new students. Thus the technologist on reading this book should become more aware of the social science dimensions of transport problems; equally the social scientist should become more aware of their technological dimensions. All readers should come to realise the complexity of most transport problems. Our second main aim is to provide that critical level of background knowledge which is essential for more advanced study, be this by courses of study or by research and investigation. Thus our book should contribute to the development of that broad understanding essential for significant advances in inter-disciplinary areas; we have provided comprehensive references to the literature to guide readers on their way to such advanced study.

There are six chapters in the book: chapter 1 on the transport sector; chapter 2 on the transport system; chapter 3 on trends in transport; chapter 4 on wider relationships between transport and socio-economic activity; chapter 5 on local transport problems and policies; and chapter 6 on national transport problems and policies.

Chapter 1 discusses the transport sector at national level in terms of such variables as employment, output, expenditure and external trade. There is some difficulty in defining the transport sector because of the pervasiveness of transport activity but a definition based on the Standard Industrial Classification is used. Thus the chapter considers specifically shipbuilding and marine engineering, vehicle manufacture, and transport and communications, transport in this context meaning transport operations. The chapter concludes by examining the importance of the transport sector for central government revenue and the way in which the transport sector features in public sector expenditure. The major contribution of this chapter is the way it inter-relates transport manufacturing, transport operations, and management of the economy by central government.

Chapter 2 discusses the characteristics of the transport system in the United Kingdom. Thus the emphasis of the chapter is on transport operations. It is structured by mode of transport with sections on the road network, private transport, public road passenger transport, road haulage, rail transport, air transport, water transport, and pipelines. It includes a final section on the organisation of transport in Northern Ireland, which differs in some measure from that of the rest of the United Kingdom.

Chapter 3 develops further the themes examined in chapter 2 and examines the main trends in the contributions by different modes of transport to transport operations. The chapter first considers overall trends in transport and notes that most transport modes are at different stages of development in a socio-economic and technological life cycle in which early expansion and growth in contribution to transport activity is followed by decline. The position of a particular mode of transport in this life cycle of development varies from country to country. It is in such a context that this book can contribute particularly to the study of 
transport in other countries. The chapter then considers trends in passenger transport with separate sections on domestic, and on international, passenger transport. The same structure is then applied to the examination of freight transport. The chapter concludes with a discussion of the relationship between trends in transport and technological change. This is an important chapter because it helps to explain trends in the contributions by different modes and how public policy has been used to affect such trends for reasons of social welfare. Such understanding is fundamental to the solution of future transport problems.

Chapter 3 having illustrated the complexity of many transport trends, chapter 4 is devoted entirely to wider relationships between transport and socio-economic activity. Transport in the general case is a 'derived' demand and so the solution to most transport problems lies in the wider relationships between transport and socio-economic activity. This chapter first considers that these relationships can be two-way; for example, increased economic activity can help to justify a new road but the road, once built, may result in even faster growth of economic activity. The chapter then considers the wider relationship between transport and economic development, between transport and social development, between transport and regional development, between transport and land-use activity, and between transport and communications.

The first four chapters of the book having been devoted to development of an understanding of transport, the final two chapters are devoted to a consideration of transport problems in the United Kingdom and ways in which they have been handled. Chapter 5 concentrates on local transport problems and policies. It argues, for example, that the underlying causes of local transport problems are general; urban scale only becomes important in the way these problems have been handled. Thus the chapter has sections on large cities, medium and smaller towns, and rural areas.

Chapter 6 is devoted to national transport problems and policies. It first makes the distinction between problem areas indirectly related to transport operation such as economic growth and regional development, energy, and transport manufacturing, and those directly related to the modes of transport operation. This determines the structure of this chapter. First there are sections on economic growth and regional development, energy, and transport manufacturing. Then there are sections on road, rail, air, and water transport, each dealing with the main national problems affecting these modes, and the ways and policies used to deal with them.

Four important themes run through the book. The first is the pervasive nature of transport activity. Most human activity has a transport element. It is because of this that it is impossible to define the transport sector in any definitive way, even though we have to do it in a more arbitrary way for the sake of analysis. It is also because of this that we must not draw the system boundaries too tightly in analyses of transport activity. The second is that transport should be dealt with as a system, with due consideration given to the effects on other modes of change in one mode, and to the inputs into the system from, and the outputs from the system to, the physical, social and economic environment. The third major theme concerns the concept of a 
life-cycle for any transport mode in socio-economic and technological terms; for example, private passenger transport may be now a dominant mode in domestic passenger transport but will this situation continue with increasing depletion of oil resources? The fourth important theme concerns the relative roles of the private and public sectors in the transport sector. At the time of writing the management of the United Kingdom economy by a relatively strict monetarist policy under the Thatcher Administration has brought into relief the whole question of the role of the public sector in transport manufacturing and transport operations. This is likely to continue to be a key area for debate in searching for solutions to transport problems in the future.

The book is the outcome of more than a decade of teaching transport studies over several courses at the University of Salford. It therefore reflects our teaching and research interests. But it also reflects the fact that many of our students, undergraduate and postgraduate, have had professional experience before taking up full-time or part-time courses or research. They have been responsible for our keeping abreast of many practical, everyday consequences of the transport objectives and policies dealt with in this book, and to them we owe a very great deal in the development of our thinking.

In particular we wish to thank Mr R. Chapman, for his help in the preparation of section 2.9 on the organisation of transport in Northern Ireland, and $\mathrm{Mr}$ P. N. Grimshaw, for the details of cement transport incorporated in section 4.2.2.

Finally, we wish to express our appreciation to colleagues at the University of Salford who helped in the preparation of the manuscript: to Mrs J. M. Bateson, Mrs L. C. Rycroft and Miss A. E. McDonnell for typing the manuscript; and to Mrs M. C. Warr, Mr G. Dobrzynski, and Mr R. Bennett for help in preparation of the artwork. 


\section{Statistical Sources}

1. Annual Reports of:

British Airways

British Airports Authority

Civil Aviation Authority

British Railways Board

London Transport Executive

Provincial Passenger Transport Executives

National Freight Corporation

National Bus Company

National Ports Authority

British Transport Docks Board

Individual ports

Transport and Road Research Laboratory

2. British Road Federation, Basic Road Statistics

3. Central Statistical Office, Annual Abstract of Statistics (HMSO)

4. Central Statistical Office, Monthly Digest of Statistics (HMSO)

5. Central Statistical Office, National Income and Expenditure (HMSO)

6. Central Statistical Office, Social Trends (HMSO)

7. Central Statistical Office, United Kingdom Balance of Payments (HMSO)

8. Chamber of Shipping of the United Kingdom (after 1974, General Council of British Shipping), British Shipping Statistics

9. Civil Aviation Authority, Monthly Statistics

10. Department of Employment, Employment Gazette

11. Department of Employment, Family Expenditure Survey (HMSO)

12. Department of the Environment, Passenger Transport in Great Britain (HMSO)

13. Department of Trade and Industry, Trade and Industry

14. Department of Transport, Transport Statistics Great Britain 1968-1978 (HMSO)

15. H.M. Customs and Excise, Annual Statement of Trade of the U.K.

16. National Ports Council, Annual Digest of Port Statistics

17. The Society of Motor Manufacturers and Traders, The Motor Industry of Great Britain 1979 